\title{
IdeAs
}

Idées d'Amériques

$6 \mid 2015$

Migrer dans les Amériques

\section{Migration, Travel Writing and Propaganda: Hungarians in Porfirian Mexico}

Migration, littérature de voyage et propagande: les Hongrois au Mexique à l'ère du Porfiriat

Migración, relatos de viaje y propaganda: los húngaros en el México porfiriano

\section{Balázs Venkovits}

\section{(2) OpenEdition}

\section{Journals}

\section{Édition électronique}

URL : https://journals.openedition.org/ideas/1182

DOI : 10.4000/ideas.1182

ISSN : 1950-5701

\section{Éditeur}

Institut des Amériques

Référence électronique

Balázs Venkovits, " Migration, Travel Writing and Propaganda: Hungarians in Porfirian Mexico », IdeAs [En ligne], 6 | 2015, mis en ligne le 10 décembre 2015, consulté le 20 octobre 2022. URL : http:// journals.openedition.org/ideas/1182 ; DOI : https://doi.org/10.4000/ideas.1182

Ce document a été généré automatiquement le 20 octobre 2022

\section{(c) (i) (9)}

Creative Commons - Attribution - Pas d'Utilisation Commerciale - Pas de Modification 4.0 International - CC BY-NC-ND 4.0

https://creativecommons.org/licenses/by-nc-nd/4.0/ 


\title{
Migration, Travel Writing and Propaganda: Hungarians in Porfirian Mexico
}

Migration, littérature de voyage et propagande: les Hongrois au Mexique à l'ère du Porfiriat

Migración, relatos de viaje y propaganda: los húngaros en el México porfiriano

\author{
Balázs Venkovits
}

\section{Introduction}

1 During the $19^{\text {th }}$ century, foreigners visiting and writing about Mexico depicted that American nation as an interesting and exotic place, but also as backward, uncivilized, and in certain respects even inferior. ${ }^{1}$ Watching it with an "imperial eye" to borrow Mary Louise Pratt's term, these writers often portrayed Mexico as the peripheral space, an underdeveloped nation (mostly in comparison with its northern neighbor), and as a country that required foreign domination for its development. The country's image abroad in the $19^{\text {th }}$ century was anything but flattering, largely due to these foreign travel accounts presenting Mexico as a dangerous land of bandits and a society of lazy and unreliable people. ${ }^{2}$ Such texts influenced how this nation was perceived abroad and thus may have contributed, among many other factors, to the fact that

[w] hereas Argentina, Brazil, Canada, and the United States received millions of newcomers during the heyday of transatlantic migration in the late nineteenth century, only 0.6 percent of all European immigrants settled in Mexico (Buchenau J., 2001: 23).

During the government of Porfirio Díaz (1876-1910, the period commonly referred to as the Porfiriato), the president and his collaborators became aware of this trend and set out to change the country's unfavorable image abroad. Aside from undertaking the modernization of Mexico, Chris Frazer points out that they also attempted to revise the 
existing negative portrayals of the country in order to attract both European capital and immigrants.

Díaz and his supporters organized an international public relations campaign to reinforce the regime's apparent durability with a veneer of cultural credibility. For this they recruited foreigners and Mexicans to lobby opinion makers and policy makers abroad and to write foreign-language 'books, pamphlets, and articles that were directly or indirectly subsidized by Porfirian authorities.' They wanted to show the world that Mexico was becoming more European and less 'Indian,' more civilized and less dangerous (Frazer C., 2006: 90).

3 This "public relations campaign" and the ongoing process of modernization under Díaz "led to a great influx of foreigners. Entrepreneurs and professionals flocked to Mexico from Britain, France, Germany, Spain, and the United States, forming sizeable foreignborn communities in the larger cities" (Buchenau, J., 2005: 92). These investors, but also travel writers, arriving in the country noted Mexico's progress - for example, the improving infrastructure, greater safety, technological development, etc. while many of them also promoted the Díaz regime in their home countries through their publications. At the same time, such commentators, several of whom were writing with governmental support, often turned a blind eye to the problems of Porfirian Mexico, that is, the negative aspects of certain policies and the controversial nature of the dictatorial Porfirian system. In such propagandistic travel writing, social problems were left out. Some Hungarian authors took part in this campaign.

The few Hungarian immigrants, travelers or soldiers who visited and wrote about the country prior to the Porfiriato borrowed the style, terminology and attitude of Western travel writers, stressing Mexico's "otherness" and "backwardness". Revolutionaries leaving Hungary after 1849 were among the first Hungarians to write about the country in detail. Károly László, Pál Rosti, and János Xántus provided fascinating but mostly negative accounts. Over a thousand Hungarian soldiers participated in the creation of Maximilian von Habsburg's Second Mexican Empire (1864-67) and several of these depicted Mexico as an underdeveloped country, in need of foreign intervention. In reports, books, and articles they were attempting to justify their own presence in Mexico as members of an imperial army. These accounts did little or nothing to promote Hungarian migration. Mexico rarely appeared independently in such reports, but mostly in relation to and in comparison with the United States, the latter portrayed as a land of opportunities and the former as a land lacking in them. Thus the revision of Mexico's image during the Porfiriato also necessitated a review of the attitude towards the northern neighbor.

5 By the turn of the century, some Hungarians visiting Mexico set out to alter the earlier depictions. They presented Mexico as a developing country and as an alternative destination for Hungarian emigration - in accordance with the objectives and no doubt with the direct support of the regime. They discussed issues of modernization and advertised Mexico as a possible new destination for Hungarians thanks to a welcoming populace and a supportive government. These texts, like Porfirian propaganda in general, were unsuccessful in luring a significant number of Hungarians to the country.

6 After providing an overview of the issue of migration and travel writing at the turn of the century, the article offers a study of the accounts of one such writer, Jenő Bánó, a Hungarian immigrant, plantation owner, who became Consul General of Mexico. It highlights his attempts to change the image of Mexico by praising the Porfiriato and 
discusses the tools with which he tried to debunk the myth of the U.S. as a land of opportunities, promoting Mexico instead.

\section{Transatlantic Migration and Travel Writing}

7 In the late $19^{\text {th }}$ and early $20^{\text {th }}$ centuries, Hungarian emigration reached unprecedented levels. A mass exodus started in the 1870s, with the United States as the leading destination. Between 1871 and 1913, about 1,200,000 Hungarians left the mother country for the emerging American nation (Puskás J., 1982: 18-19). Compared to such a large wave, other parts of the Americas, including Mexico, remained marginal. According to Gusztáv Thirring, "our fellow countrymen have emigrated to Central America only in small numbers and occasionally; according to the statistics of German ports only 39 Hungarians left for that region in thirty years (...) and the number of Hungarians living there is insignificant" (Thirring G., 1904: 88). ${ }^{3}$ It is difficult to estimate the number of Hungarians in Mexico at the time since the registration of immigrants was required only from the beginning of the 1900s and was made even more difficult by the fact that many Hungarians identified themselves as Austrian or German so as to avoid the term húngaro which in that time was used also as a synonym for gypsies (Szente-Varga M., 2012: 45). The Austro-Hungarian colony consisted of only a few hundred members and "no signs of significant Hungarian immigration were found" (Ibid., p. 44). Several factors contributed to such the great differences in the number of immigrants settling in these two countries. Julianna Puskás, while emphasizing the economic causes of this mass movement and stressing the significance of the pull factors of the United States, claimed that "[n]umerous other factors also played their part in the mechanism of emigration - factors not so much economic but rather social and psychological in nature, and these by and large elude quantification" (Puskás J., 1982: 56). One such often overlooked, may be the image Hungarians had of the two countries at the time; an image that was shaped to a great extent by travelers' accounts. Before the period of "New Immigration" beginning in the 1880s, the U.S. was often viewed with "reverent admiration" in Hungarian travel writing (Katona A., 1971). The pull factors of the country were intensified both by travelogues and by the news arriving from the U.S. By the end of the century such news was much more abundant thanks to of the transatlantic cables. There was more access to information on American progress, the second industrial revolution, railroads, world fairs, politics and job opportunities (Ibid., p. 53). Information from Hungarians already living in the U.S., in the form of Amerikás levelek or letters from America, also expressed a positive view, often reporting only on success and equality. This went contrary to the Hungarian government publications that tried to highlight and emphasize the hardships of life in the United States (Glant T., 2010: 176.)

8 A similarly positive image, reinforced by different sources, was not available in the case of Mexico. The country was portrayed by travel writers as dangerous because of bandits roaming the countryside, politically unstable, unpredictable, and with only sporadic Hungarian presence and no real opportunities for Hungarian migrants. The population was also usually represented as problematic; compared to U.S. and Western European citizens, Mexicans were seen as lazy, superstitious, and uncivilized. Hungarian travel writers such as Károly László, János Xántus, Pál Rosti, Ede Pawlowszki reinforced such negative depictions. Although they also presented the country as exotic and 
interesting, all in all they offered an inauspicious image of Mexico for armchair travelers and potential immigrants.

Publications by immigrants represent a special form of travel writing. Just as in the case of other types of travelers, their descriptions tell just as much about themselves (the self) as the country and people described (the other). Comparisons and contemplations, however, are more complex and complicated in the case of those who are forced to leave behind the mother country often without knowing if they could ever return. As a result of the circumstances of their journeys, these travelers carry an (invisible) luggage that clearly influences their perceptions and accounts. They need to address various issues: they ponder whether the foreign land will become their new home permanently, whether such a change requires them to alter their way of life and thus whether the journey requires leaving behind their home culture and identity exchanging it for a new one. Due to their different emotional (and financial) engagement (compared to tourists and travelers), immigrant accounts differ from travelogues written by people visiting a country for a shorter period only. Long-term engagement influences the topics introduced as immigrants write not only about major sights or attractions but also offer more insights into everyday life and tips for possible future emigrants. As a result, their audience also differs and thus they often write with a different purpose. Some, like Bánó, use travel writing to advance their career in the new country or to offer criticism of their home; others might publish their experience to explain their decisions for a home audience or to build a reputation before returning home. ${ }^{4}$ Writing as an immigrant also often reveals a confused identity; people are caught between two spaces: still attached to the mother country but already beginning to assume a new identity. Bánó serves as an example in this regard.

\section{Changing Depictions of Mexico and the United States}

Prevailing images of the United States and Mexico began to change during the period of unprecedented migration. Travel accounts reflected the hopes and fears of immigrants and were often used to either encourage or discourage migration. In the case of the US, as Katona claims, "the eleven travelogues published in Hungary between 1877 and 1900 bear little or no resemblance to the ten travel books written between 1834 and 1863" (Katona A., 1973: 35). András Vári goes as far as to claim that "the model country of the Reform Era became the land of threats by 1890" (2006: 153). Tibor Glant provides a more balanced view and concludes that although critical voices became more emphatic, the myth of the land of opportunities still survived in both a political and economic sense (2012: 79-99). Still, many Hungarian travelogues became more critical of the US in this period and called attention to the downsides of the Gilded Age and mass immigration (Katona A., 1973: 37). The anti-American sentiment of the era as expressed in these writings was due to three main factors: "a major shift in the way Hungarians came to view the future of their own country, an imperial approach to the New World, and large-scale trans-Atlantic migration" (2010: 175). In published accounts, more emphasis was put on the hardships of the trans-Atlantic voyage and the harsh treatment and low ranks of recent immigrants, among other issues (Glant T., 2012). This changing image in Hungarian travel writing was augmented with the various Hungarian government publications mentioned above. 
11 At the same time, with regard to Mexico, more complimentary views were published that noted modernization and (directly and indirectly) even called people's attention to business opportunities, in line with the intentions of the Mexican government. Foreign travelers were eager to report on Porfirian progress and modernity, especially if they had a personal interest in it. Images focused on developing infrastructure, especially the railroads, with the Mexico-City Veracruz line, inaugurated in 1872, as the iconic example. This was supported by images of progress in industry, emerging nationalism, as well as growing safety, the latter representing a response to an often-criticized feature of the country. To combat banditry in Mexico, a new police force (the rurales) was established by Díaz and this created order in the countryside, while also improving the image of the country abroad: "under Díaz the rurales achieved international acclaim as one of the most effective mounted police forces in the world. This was more often a matter of effective publicity than of actual fact, and a good part of this reputation resided in the glamour associated with the official rural police uniform, modeled after the charro outfit worn by the Plateados" (Frazer, C., 2006: 85).

12 Foreign travel writing noted and celebrated the perceived progress: "Mexico now had, in the eyes of some, the technological and industrial markers of modernity. Alongside the older views of Mexico, the nation began to look modern and progressive" (Ruiz, J., 2012: 921). Many writers celebrated Díaz himself. Marie Robinson Wright, for example, dedicated her work Picturesque Mexico (Philadelphia, J.P. Lippincott, 1897) to the Mexican President with the following words:

To Senor General Don Porfirio Díaz, the illustrious President of Mexico, whose intrepid moral character, distinguished statesmanship, and devoted patriotism make him the pride and glory of this country is dedicated this volume, describing a beautiful and prosperous land, whose free flag never waved over a slave, and whose importance as a nation is due to the patriot under whose administration Mexico now flourishes and holds its proud position among the republics of the world.

Hungarian travel writing followed this trend and a growing number of texts were published in which Hungarians called for a (what they called) more realistic and fairer representation of the country and its people, trying to refute earlier negative impressions and also calling attention to good prospects in Mexico. In earlier travel accounts, even if business and agricultural investment opportunities were mentioned in Mexico, they were usually not presented as viable options for Hungarian immigrants, they mostly emphasized the role of the United States (or Western Europe) in "civilizing" the nation and making use of the country's resources. This attitude changed during the Porfiriato.Vilmos Sennor, for example, wrote in a new tone as early as 1889. According to Vasárnapi Újság (one of the most popular weekly papers of the time), Sennor moved to Mexico in 1880 "where his business ventures came off well, and he gained a good reputation and general esteem among his new fellow-citizens." What is more, it is even claimed that "he was a true guardian and father of those few Hungarians who found themselves there and he always tried to advance their cause in all possible ways." ${ }^{5}$ In his articles published in Hungary, he presented a more positive image of Mexico than those writing before him, even if he called attention to the fact that "not everything was gold in America" and "many people who came in search of gold had become disappointed." ${ }^{\circ}$ Sennor paints a different picture of Mexican progress than those writing before him: he claims that the previous ten years witnessed unprecedented growth and development and "Mexico is being born." The country is presented as one of the richest parts of the world, with fertile land and unmatched 
resources. Immigrants, workers, and those having capital are needed, however, to continue progress. Sennor states that it is unavoidable that Europeans will come to the Americas in large numbers and he actually encourages Hungarians to emigrate to Mexico (even planning the establishment of a Hungarian village with a wealthy friend (and with governmental support)). He invited Hungarians but also warned them: "so come if you wish, but not with the dream of finding treasure right away; those emigrating should keep in mind that they have to work to advance anywhere they decide to go, otherwise they had better stay home" (Ibid).

The first touristic accounts of Mexico also appeared in Hungary during the Porfiriato and presented a welcoming atmosphere in the country. The first such account was written by a woman, Mrs. Béla Mocsáry, who promoted the image of a safe country, where a woman can also travel on her own and introduced her readers to an "unfamiliar place" where "the well-being of the population can be seen" (Mocsáry B., 1905: 8).Mocsáry includes no criticism whatsoever of the Porfiriato but praises the country for its modernization and progress. Her book also features the photo of Díaz on the very first page and there are both direct and indirect references to contacts with officials of the Mexican government in the travel account. Due to the perceived safety in the country, Mrs. Mocsáry was not alone as a tourist: at the turn of the century "under the new calm, tourists became a common sight. [...] The first guidebooks had appeared in the 1880 's, and in the last two decades of the century nearly sixty books of travel were published by American and British writers" (Drewey W., 1974: 40).

The best example for illustrating the changing depictions of Mexico and the links between travel writing and propaganda is a pioneering figure in Hungarian travel writing, Jenő Bánó. He presented a novel attitude towards his adopted home and as part of this endeavor redefined the perception of the relationship between the US and Mexico, and set out to mend the image of Mexico in Hungary, including its attractiveness for immigrants. As a review of his first book in Vasárnapi Újság claimed on October 19, 1890, "the book has current value as well, at a time when so many people emigrate in search of a new homeland."

\section{"We are Clearly Deceived at Home": Jenő Bánó and a New Mexico}

Similarly to many of his compatriots, Jenő Bánó (1855-1927) left the mother country at the end of the $19^{\text {th }}$ century with the aim of working in the United States, looking for employment opportunities and ways to earn money: "if I am lucky, I can return to my homeland where we will enjoy the fruits of my work together [with my family]" (Bánó J., 1890: 115-116). After a few months in the United States, however, he moved to Mexico, started various business ventures there, and wrote about his experience in the Americas for a home audience. From the first publications onward, it was his clear aim to alter the former image of Mexico, offer a more favorable account, and call attention both to the beauties of and opportunities in the country. He also criticized former travel writers for their hostile mistreatment of the nation:

It is obvious that we are deceived at home as the small number of books written about Mexico, and in common use in Austria and Hungary, contain more malevolence towards Mexicans than honesty (...) We Hungarians, while reading Austrian books on Mexico, might well remember when a few years ago our good 
friends wrote about us in a very similar fashion, moreover, the dear German Schulverein still likes to present us to foreigners as outlaws and semi-barbarians (Bánó J., 1890: 77-78). advance his own career in his new home. In a letter to his father, he wrote: "The publication of my work and its translation to Spanish later on can bring me a bright future in Mexico as it is probably the first work to introduce the local conditions benevolently and fairly" (Ibid., p.198). He also made sure that Díaz himself would be informed of this positive treatment of Mexico in his books. His publications, as he hoped, were well received in Mexico: a review of his first book praising the Hungarian for his fair and positive treatment of Mexico and a letter from Díaz himself in which the President promised support for Bánó's Mexican endeavor, were republished in Bánó's book and stand as witness that Mexican authorities were informed about the contents of Bánó's writings (Bánó J., 1896: 25). Bánó presented Mexico as a modern and civilized country with a friendly and welcoming population, an image directly opposed to earlier depictions. Because of this overtly complimentary stance and the praise he received for it, Szente-Varga refers to Bánó simply as "publicist of the Porfiriato" (2012: 47).

After leaving his home country and visiting various cities in Europe, Bánó arrived in New York in May 1889 and traveled in the United States. He planned to settle in the country but after spending a month and a half in San Francisco (and not finding proper employment) he moved "to the empire of the famous Aztecs, the present Republic of Mexico, to personally see whether all those news about this beautiful country and its people are true" (Bánó J., 1890: 7). Bánó was actually referring to work and investment opportunities in Mexico, establishing coffee plantations in particular, that he had heard about. Bánó bought land and founded a coffee plantation in Oaxaca and named it Camilla after his late wife. Later he married a Mexican woman of Zapotec origin, with whom he traveled extensively in Central and South America, including Venezuela, where he stayed and worked for a year, Cuba, Columbia, Costa Rica, Nicaragua, Honduras, El Salvador, and Guatemala. Later he established other plantations, which he named Hungária, Hunnia, and Pannonia, and also started to grow vanilla, sugar cane, and rubber trees. However, these plantations were destroyed by a tornado before they could bring any profit (Bánó J., 1906: 337).

Looking for new opportunities after this financial disaster, Bánó moved to Mexico City. It was here that he met the President of the Republic and was offered (unexpectedly as Bánó himself wrote) the position of Consul General in the newly established Mexican Consulate in Budapest (where he held the position between 1903 and 1912). ${ }^{7}$ The commission itself can be seen as an indication of his connections and may be attributed to his favorable publications about Mexico (that have already been available by this time) and a tendency on his part to emphasize the importance of commercial ties between Mexico and Hungary. Thus, Bánó returned to Hungary after spending several years in the Americas, this time as a representative of the Mexican government.

Bánó wrote extensively about his journeys and life in the Americas resulting in three books (Uti képek Amerikából [Images of a journey in the Americas], Mexico és utazásom a trópusokon [Mexico and my travels in the tropics], Bolyongásaim Amerikában [My wanderings in the Americas]) and a number of shorter publications as well. The texts mostly concerned Mexican life, descriptions of Mexico and Mexicans, Indians, and introduced numerous Mexican goods while Bánó also called attention to possible 
commercial opportunities for Hungarians. In his books and other texts Bánó not only introduces the readers to what it was like to live on the other side of the Atlantic but also provides a glimpse into the psyche of immigrants and the questions always haunting them: did I make the right choice when leaving my family? Was it worth coming to America? Did I choose the right place to settle? These questions made Bánó continuously ponder on his relationship with the home country and the new land, on questions related to travel, migration, and his future. As an immigrant writer, his primary concern was not to introduce the main sights but to focus on life in Mexico, combined with criticism of the home country and the discussion of novel topics: these included studies on how to grow vanilla and coffee, how to start a business in Mexico, etc. Bánó claims in his book that after reading his publications several Hungarians contacted him about opportunities in the country (Bánó J., 1896: 183): "I am not surprised that many people want to emigrate from Hungary" (...) It seems that soon a Hungarian colony will be born under the Mexican sky for which Mr. Kálmán Tisza [Hungarian Prime Minister] will pass the death penalty on me and all my coffee in contumaciam" (Ibid., p. 191). Due to his long-term emotional attachment and plans in the country, he provides a much more favorable image of the country than those Hungarians who wrote before him.

\section{Mexican Images Revised}

21 Bánó's novel approach was influenced by numerous factors. His status as an immigrant in Mexico during the Porfiriato affected his attitude towards the representation of the country in a crucial way. He knew that a favorable account could help the realization of his plans in the country, thus he was planning publication of his experience from an early stage of his stay in the New World (see for example Bánó J., 1890: 131 and 198) and he consciously worked on demolishing former negative images. Bánó is eager to share with his readers the signs of modernization and improvement in Mexico, similarly to other foreign writers of the time. He travels on and describes the various new railroads that he points out as new projects bringing progress to the cities and the country in general. He presents technology available in the country, together with signs of industrialization, success in mining, and great opportunities in agriculture as well. Mexico is seen as a country moving forward in enormous steps. "In the last few years mostly after the influence of the clergy has been broken - the country has made such significant progress in the field of industry, commerce, arts, and science that it has earned the respect of Europe a long time ago and especially deserves to be taken out of the line of terra incognita and to receive more attention from us as well than before" (Ibid., p. 79). Even if in certain aspects Mexico is mentioned as less civilized than Europe, there are no references to any kind of inferiority, and there is a strong emphasis on the future rise and development of the nation.

His former experience in the United States shaped his view of Inter-American relations and altered its depiction: having found no work, he was disappointed in the US, thus he willingly emphasized the downsides of immigrant life there and contrasted them with opportunities in Mexico. While the United States serves as a main reference point when using triangulation, it is not seen as a model to be followed without reservations any more, but as a threat to Mexico's unique culture and national identity. 

Hungarian history in terms of continuous struggles with great powers. Bánó believed that both Mexico and Hungary were misrepresented by Western, imperial powers before and draws parallels, although on rather questionable grounds and with dubious reasoning, between Hungarian and Mexican history: while Mexicans were oppressed by the Spanish and have lived under the influence of the United States, Hungary lived under foreign rule for centuries and now lives in the shadow of the Habsburg Empire. "Just like we Hungarians, who suffered under foreign influence for centuries, they also felt the Spanish yoke on their necks for hundreds of years, and just like us Hungarians getting rid of our handcuffs would like to enjoy the hardly-won freedom and just as we are looking for the love and respect of foreign nations, the Mexicans are also happy about their freedom and strive to win the esteem of foreign countries" (Ibid.). He demands fair treatment for Mexico and emphasizes the significance of preserving the unique identity (and independence) of the country. At the same time, US influence is seen as harmful, unlike in the case of László and Xántus, it is not a model to be followed any more by Mexico; it becomes dangerous for the Mexican national character, just like Austria's rule over Hungary is:

[Mexicans] do not like the North Americans and still their influence expands day by day; but in my humble opinion this with time can pose a threat for this young state that has just started to flourish and which as an independent republic is destined to a great role, if, however, they would unite with North America, the country would lose its originality, unique features, and nationality among the Anglo-Saxons - as it happened in California, New-Mexico, and Texas - and it would be degraded to a secondary position within this enormous body (Bánó J., 1890: 96).

Mexico could give him what the US did not: good prospects for an immigrant. While he calls attention to threats on immigrants and no great opportunities are introduced in the US, Bánó presents a completely different image of Mexico: Mexican accounts emphasize Hungarian success stories, a welcoming environment and people, and good opportunities for immigrants. Bánó depicts Mexico as an alternative destination for Hungarians.

Banó's positive treatment of Mexico materializes in numerous ways. The populace is introduced in overtly positive terms and the former stereotypical image of a lazy and uncivilized population and that of Mexico as a land of bandits is revised in Bánó's texts and all social and ethnic groups receive a favorable treatment, people are presented as kind, hospitable, as well as good workers. Such accounts, however, do more than just take note of development that certainly took place in Mexico at the time. Bánó identifies with the policies of the Díaz government and projects his positive view of progress in the country to all aspects of life, remaining blind to problems of the nation.

Bánó emphasizes the role of Porfirio Díaz in Mexican modernization and praises him for his achievements and his strict rule of the country. The Mexican leader is acclaimed and supported throughout the books and even photos and stories are included of him, together with a letter from the President thanking Bánó for his attitude and the positive image of Mexico in the Hungarian's first book. Bánó offers no criticism of the Porfiriato and does not note any problems of the Mexican population. This is not the only contradiction in his works. While Bánó criticizes the imperial powers for their treatment of Mexico (and Hungary), he also hails progress that the Díaz regime wanted to achieve with the involvement of US and Western European capital, workforce, and expertise (as, for example, in the case of the construction of railroads by the English). 
Bánó's immigrant background and its influence on travel writing are discernible also in his treatment of migration itself. Bánó encouraged Hungarian immigration to Mexico both indirectly by the complimentary depiction of the country and also more explicitly: "This is Mexico, dear father, a really blessed country and anyone who has a practical mind is destined to become rich here" (Ibid., 139). Bánó goes even further and writes: "It would be wiser for our Tóts [people of Slovak ethnicity living in the territory of Hungary], if they want to emigrate from the upper parts of our county, to come here and not to the unfortunate North America [i.e. the United States] where they are looked upon as draft animals" (Ibid., p. 195). While in the US he presents the difficult circumstances of Hungarian immigrants, in Mexico he stresses success. He writes about six Hungarians in Mexico City and claims that "all my Hungarian compatriots have a successful life both socially and financially, and what is even more important, they are all loved and respected both by Mexicans and others" (Ibid., p. 108). In Bánó's depiction, Hungarians have a much better status in Mexico than in the US and also mentions the example of Samu Lederer, his influential Hungarian friend and patron in Mexico City, who could not cope in the US but became successful in Mexico. Besides writing about his own experience and projecting a generally positive image, Bánó also provides practical advice for Hungarian readers, offering growing tips, describing workers and their fees, the challenges of immigrant life, and also calling attention to the support granted by the government, and realizable profits. Bánó also notes that the demand for labor force cannot be satisfied by Indians only in the future, so emigration will be needed that can come either from Asia or Europe. "I believe both me and the government would give the advantage to European emigration and will not bring in only in greatest need - the Chinese who have flooded California and the West coast of North America so much that Americans are trying to get rid of them by all means" (Ibid., 195). Bánó's books provide a mixture of a typical travelogue, migrant narrative, and propaganda. With his attitude Bánó created a novel Mexican image in Hungarian travel writing on Mexico that had been associated only with the US before.

\section{Conclusion}

Bánó's belief in the policies of the Porfiriato and the great future of Mexico (coupled with his career plans in the country and the fact that favorable publications could be beneficial in achieving them) shaped his portrayal of the entire country and its population. The Hungarian projected his positive view of progress in the country to all aspects of life. Therefore, compared to previous travel accounts, Bánó depicts a much safer country (with no threats by bandits), previously ill-treated groups within society receive a more favorable presentation, people are seen as kind, hospitable, as well as good workers. When Bánó writes negatively about certain people or groups, these examples are only treated as exceptions to the general rule. Bánó emphasizes the role of Porfirio Díaz in Mexican modernization and praises him for his achievements and his strict rule of the country. He is acclaimed and supported in the books where even photos and stories are included of the Mexican leader (along other government officials), together with a letter from the President thanking Bánó for his attitude towards Mexico expressed in his first book. Bánó offers no criticism of the Porfiriato and did not note problems of the Mexican population, remaining blind to the troubles of the nation. 
of sublications clearly supported and participated in the campaign of the Porfiriato to establish a new image for the country to attract more immigrants to the nation and were clearly influenced by his status as an immigrant. Porfirian propaganda, however, was unsuccessful and could not achieve its objectives:

As a receiving country, Mexico has played a marginal role in the great migrations of the last two centuries. Although rich in natural resources and economic opportunities, it was poor in available land and jobs for lower-class immigrants. Not even the Porfirian propaganda - persuasive as it was in luring foreign investment could convince more than a tiny fraction of all Europeans who embarked for the Americas to try their luck in Mexico (Buchenau, 2001: 44).

In this sense Bánó failed also: he did not succeed in luring significant numbers of Hungarians to Mexico and could not reverse the unfavorable image of the nation in his home country on the long run. Still, he must be considered as a crucial figure in Hungarian travel writing on Mexico for his attempts to offer an alternative approach towards the country and its population. Bánó claimed that former travel writers had deceived Hungarians by presenting only the negative aspects of life in the country. This is certainly true but applies to Bánó as well: he advertises Mexico but does not notice the problems of the country and the adverse sides of the Porfiriato that resulted in a revolution within a few years. Travel accounts were used partly to advance his career in the New World and travel writing served the propagandistic purposes of the Mexican government.

\section{BIBLIOGRAPHIE}

Bánó Jenő, Úti képek Amerikából, Budapest, Franklin, 1890.

Bánó Jenő, Mexikó és utazásom a trópusokon, Budapest, Kosmos, 1896.

Bánó Jenő, Bolyongásaim Amerikában, Budapest, Athenaeum, 1906.

Buchenau, Jürgen, Mexico Otherwise, Albuquerque, University of New Mexico Press, 2005.

Buchenau, Jürgen, “Small Numbers, Great Impact: Mexico and Its Immigrants, 1821-1973," Journal of American Ethnic History, vol. 20, Spring 2001, p. 23-49.

Drewey, Wayne Gunn, American and British Writers in Mexico, 1556-1973, Austin, University of Texas Press, 1974.

Frazer, Chris, Bandit Nation: A History of Outlaws and Cultural Struggle in Mexico, 1810-1920, Lincoln, University of Nebraska Press, 2006.

Fuente, José Iturriaga de la, Anecdotario de viajeros extranjeros en México, siglos XVI-XX, Mexico, Fondo de Cultura Económica, 1988-92.

Glant, Tibor, “Dualizmuskori Amerika-kép, utazási irodalom és paródia,” in Zoltán Varga, (ed.), Essays in Honor of György Novák, Szeged, JATE Press, 2012, p. 79-99.

Glant, Tibor, "Travel Writing as a Substitute for American Studies in Hungary," Hungarian Journal of English and American Studies, vol. 16, n.1-2, 2010, p. 171-184. 
Glant, Tibor, Amerika, a csodák és csalódások földje. Az Amerikai Egyesült Államok képe a hosszú XIX. század magyar utazási irodalmában. Debrecen: Debreceni Egyetemi Kiadó, 2013.

Katona, Anna, "Hungarian Travelogues on Pre-Civil War America," Angol Filológiai Tanulmányok vol. V, 1971, p. 51-94.

Katona, Anna, "Nineteenth-Century Hungarian Travelogues on the Post-Civil War United States," Angol Filológiai Tanulmányok, vol. VII, 1973, p. 35-52.

Lynn V. Foster, A Brief History of Mexico, New York, Facts on File, 2010.

MacLachlan, Colin M., and William H. Beezley, El Gran Pueblo: A History of Greater Mexico, N.J., Prentice Hall, 2004.

Mocsáry Béláné Fáy, Mária,Mexikói utazásom, Budapest, Pesti Könyvnyomda, 1905.

Navarro, Moisés González. Los extranjeros en México y los mexicanos en el extranjero, 1821-1970. vol. 2. México, El Colegio de México, 1994.

Navarro, Moisés González, Sociedad y cultura en el porfiriato. México, CONACULTA, 1994.

Pawlowszki, Ede, Miksa császár mexikói szerencsétlen expeditiójának leírása, Budapest, Rudnyanszky, 1882.

Pitman, Thea, Mexican Travel Writing, Oxford, Peter Lang, 2008.

Pratt, Mary Louise, Imperial Eyes: Studies in Travel Writing and Transculturation, London, Routledge, 1992.

Puskás, Julianna, From Hungary to the United States (1880-1914), Budapest, Akadémiai Kiadó, 1982.

Ruiz, Jason, "Desire Among the Ruins: The Politics of Difference in American Visions of Porfirian Mexico," Journal of American Studies vol. 46, no. 4, 2012: 919-40.

Rosti, Pál, Uti emlékezetek Amerikából,Pest, Heckenast Gusztáv, 1861.

Szente-Varga, Mónika, A gólya és a kolibri: Magyarország és Mexikó kapcsolatai a XIX. századtól napjainkig, Budapest, Áron Kiadó, 2012.

Szente-Varga, Mónika, “'Bajo el cielo mexicano pronto se formará una colonia húngara': Imagen de México en la obra Mis aventuras en América de Eugenio Bánó," in Josef Opatrny, (ed.), IberoAmericana Pragensia, Supplementum XIII, Prague, Universidad Carolina de Praga, 2005, p. 127-135.

Szente-Varga, Mónika, Migración húngara a México entre 1901 y 1950, Puebla, Instituto de Ciencias Sociales y Humanidades, 2007.

Thirring, Gusztáv, A magyarországi kivándorlás és a külföldi magyarság, Budapest, Fritz Armin, 1904.

Torbágyi, Péter, Magyarok Latin-Amerikában, Budapest, Magyar Nyelv és Kultúra Nemzetközi Társasága, 2004.

Torbágyi, Péter, Magyar kivándorlás Latin-Amerikába az első világháború előtt, Szeged, Szegedi Tudományegyetem, 2009.

Vári, András, "Fenyegetések földje. Amerika a 19. század második felében - magyar szemmel," Korall, vol. 7, $\mathrm{n}^{\circ}$ 26, 2006, p. 153-85.

Venkovits, Balázs, "Writing with Devotion, Drawing with Light: Images of the Americas in Nineteenth Century Hungarian Travelogues," in Grzegorz Moroz and Jolenta Sztachelska, (eds.), Metamorphoses of Travel Writing: Across Theories, Genres, Centuries and Literary Traditions, Newcastle upon Tyne, Cambridge Scholars Publishing, 2010, p. 104-113. 
Venkovits, Balázs, "Describing the Other, Struggling with the Self: Hungarian Travel Writers in Mexico and the Revision of Western Images," Journeys: The International Journal of Travel and Travel Writing, vol. 12, $\mathrm{n}^{\circ} .2,2011$, p. 28-47.

Venkovits, Balázs, "Revisiting the Legacy of János Xántus: An Inter-American Approach," in Ruttkay Veronika and Gárdos Bálint, (eds.), HUSSE 11: Proceedings of the 11th Conference of the Hungarian Society for the Study of English, Budapest, L'Harmattan, 2014, p. 495-510.

Xántus, János, Levelei Éjszakamerikából, Pest, Lauffer és Stolp, 1858.

Xántus, János, Utazás Kalifornia déli részeiben, Pest, Lauffer és Stolp, 1860.

\section{NOTES}

1. This research was realized in the frames of TÁMOP 4.2.4. A/2-11-1-2012-0001 "National Excellence Program - Elaborating and operating an inland student and researcher personal support system." The project was subsidized by the European Union and co-financed by the European Social Fund."

2. For more information see for example Buchenau J., 2005 and Pitman T., 2008. For more details on Hungarian travel writing on Mexico before the Porfiriato see for example Venkovits B., 2011 (see the Bibliography for details).

3. Unless otherwise noted, all translations of Hungarian texts are mine.

4. See, for example, Venkovits B., 2014.

5. “Egy magyar ember sírja Mexikóban," Vasárnapi Újság, June 12, 1898.

6. “Levél Mexikóból,” Vasárnapi Újság, November 17, 1889.

7. For details see Torbágyi P., 2009. For changes in diplomatic, economic, and cultural relations see Szente-Varga M., 2012, 28-44.

\section{RÉSUMÉS}

Cet article étudie la relation entre migration, récit de voyage et propagande durant le Porfiriato au Mexique. Au $19^{\mathrm{e}}$ siècle, les observateurs étrangers et les voyageurs donnaient une image défavorable du Mexique, insistant non seulement sur les différences mais aussi sur l'arriération du pays, en particulier comparé aux Etats-Unis et à l'Europe de l'Ouest. Porfirio Díaz a voulu modifier cette perception négative du pays à l'étranger, s'appuyant entre autres sur la littérature de voyage pour propager une nouvelle image du Mexique : celle d'une nation moderne et civilisée accueillante pour le capital étranger (européen) comme pour les immigrants. Certains auteurs hongrois ont participé à cette « campagne » pour changer l'image du pays ; plusieurs publications sont parues en Hongrie dans le but de changer l'ancienne perception négative et de présenter le Mexique comme une possible destination d'immigration hongroise. L'article, après une discussion des liens entre la migration hongroise en Amérique du Nord et la littérature de voyage, étudie le cas de l'auteur hongrois Jenő Bánó. Il analyse les objectifs de ses publications, leur relation à la propagande porfirienne et les outils utilisés pour un type d'écriture qui tentait de remettre en cause l'image des Etats-Unis comme terre d'opportunités et d'y substituer le Mexique. 
This paper examines the relationship between migration, travel writing, and propaganda during the Porfiriato in Mexico. During the $19^{\text {th }}$ century, foreign observers and travel writers projected an unfavorable image of Mexico, stressing not only the country's otherness but also its backwardness, especially in comparison with the United States and Western Europe. Porfirio Díaz set out to alter this negative view of the country abroad, among other things with the help of travel writing and by propagating a new image of Mexico: that of a modern and civilized nation that welcomes foreign (European) capital and immigrants as well. Some Hungarian writers also took part in this "campaign" to change the country's image; several publications appeared in Hungary aimed at altering the former negative portrayal of Mexico and presenting it as a possible destination for Hungarian emigration. The paper, after discussing the links between Hungarian migration to North America and travel writing, offers a case study of one Hungarian writer, Jenő Bánó, and his books. It studies the purposes of his publications, their relation to Porfirian propaganda, and the tools used for a type of writing that attempted to debunk the image of the US as a land of opportunities while advertising Mexico instead.

Este articulo estudia la relación entre migración, relato de viaje y propaganda durante el Porfiriato en México. En el siglo 19 los observadores extranjeros y los viajeros daban una imagen desfavorable de México, insistían no solamente sobre la diferencias sino también sobre el retraso del país, en particular comparado con los Estados Unidos y con Europa Occidental. Porfirio Díaz quiso modificar esta percepción negativa del país en extranjero, apoyándose entre otras cosas en la literatura de viaje para propagar una nueva imagen de México: aquella de una nación civilizada acogedora tanto para el capital extranjero (europeo) como para los inmigrantes. Algunos autores húngaros participaron en esta "campaña" para cambiar la imagen del país, muchas publicaciones aparecieron en Hungría con el objetivo de cambiar la antigua percepción negativa y presentar México como un posible destino de la inmigración húngara. El artículo, después de discutir los lazos entre migración húngara en América del Norte y la literatura de viaje, estudia el caso del autor húngaro Jenő Bánó. Analiza los objetivos de sus publicaciones, su relación con la propaganda porfiriana y los instrumentos utilizados por un tipo de escritura que intentaba cuestionar la imagen de los Estados Unidos como tierra de oportunidades y de substituirla por la de México.

\section{INDEX}

Mots-clés : littérature de voyage, Hongrie, immigration, propagande, Porfiriato

Palabras claves : literatura de viaje, Hungría, inmigración, propaganda, Porfiriato

Keywords : travel writing, Hungary, immigration, propaganda, Porfiriato

\section{AUTEUR}

\section{BALÁZS VENKOVITS}

Balázs Venkovits teaches at the North American Department of the Institute of English and American Studies, University of Debrecen, Hungary. He earned his M.A. degree from the University of Debrecen in 2007 and was awarded a Ph.D. in 2014. His broader academic interests include travel writing studies, 19th-century Hungarian travel accounts on Mexico and the United States, and US-Hungarian relations. He teaches courses on American civilization, history, travel writing, translation, and also works with students in various language classes. His current research focuses on the evolution of the image of Mexico in Hungary, especially in an interAmerican comparison with that of the United States. His articles have been published in 
Hungarian and English, he is currently working on his book on Hungarian travelers in North America. For a list of publications and CV visit his website: http://ieas.unideb.hu/venkovits? l=en ; balazs.venkovits@gmail.com. 